\title{
A Nation and Bureaucracy: An Indonesian Case
}

\author{
Ayuning Budiati \\ University of Sultan Ageng Tirtayasa \\ Banten, Indonesia \\ ayoekomara@gmail.com
}

\author{
Diani Indah \\ University of Langlangbuana \\ Bandung, Indonesia
}

\author{
Idi Jahidi \\ Academy Secretary and Management of Ariyanti \\ Bandung, Indonesia
}

\begin{abstract}
Indonesia is a big nation which has hundred millions population and thousands of islands. Indonesia as a nation is still facing obstacles regarding inefficient and ineffective bureaucracy. For example, many investors are reluctant to conduct business in this country due to collusion and corruption activities because of long and expensive bureaucracy. Inefficient bureaucracy in providing better public service is also worsening investment activities in Indonesia. Red tapping occurs when foreign investors have intention to conduct their activities in our nation. This essay argues there are three factors of public administration need to be implemented in order to improve nation and bureaucracy's function effectiveness, namely recoding bureaucrats, implementing the ideal of administrative responsibility and best value. The method of this research is descriptive analysis and it uses qualitative approach. The data for this researh is found by literature review. Books and journals use for literature review. The results for this paper are there is a need for the implementation of three factors in an integrated way, namely recoding bureaucrats, implementing the ideal of administrative responsibility and best value for creating good governance.
\end{abstract}

Keywords-best value, recoding, Indonesian bureaucrat

\section{INTRODUCTION}

Bureaucracy is a set of system in government to give public service delivery. As Bintoro Tjokroamidjojo in [1] states, bureaucracy is a type of organization that is used by modern government to conduct various specialist duties in an administration system and especially by civil servants. Based on that definition and condition that ideal bureaucracy has some prerequisites - such as clear responsibility and job specification, organizing hierarchical position, good regulation, good obligation based on rational standard (Weber) - then, a nation and public administration need good bureaucracy to achieve their goals. In this modern era, bureaucracy moves toward modern bureaucracy. Meaning it becomes 'impersonal, rational, specific, achievement-oriented and universalistic [2], then there is a need of more modern public administration, meaning it is more professional and becoming more "rowing rather than steering".
Bureaucracy, as personal and institutional forms, is a nation organ that has a function to conduct public service delivery; whilst public administration is a cooperation process among people to achieve their goals. Public administration as cooperation activities within public organization - or nation needs bureaucracy to achieve its goals. Meaning, without good bureaucracy then public administration cannot operate well; hence nation's goals would not be achieved.

Currently, Indonesia as a nation is still facing obstacles regarding inefficient and ineffective bureaucracy. For example, many investors are reluctant to conduct business in this country due to collusion and corruption activities because of long and expensive bureaucracy. Inefficient bureaucracy in providing better public service is also worsening investment activities in Indonesia. Red tapping occurs when foreign investors have intention to conduct their activities in our nation. Further example is Indonesian bureaucracy has failed to conduct its function which is providing public service delivery.

Based on that Indonesian bureaucracy example, it is clear that Indonesia has the traditional model of bureaucracy. Meaning, bureaucracy is inefficiency in achieving organization's goals. As Behn (1998) in [2] argues that bureaucracy is as a synonym for inefficiency, it is producing inertia, lack of enterprise, red tape and mediocrity. Bureaucracy in traditional model has in efficiency characteristics, such as it is rigid, secrecy, hierarchy and more formal. People have to follow many procedures that take more time and more expensive to get public service. For example, people have to bribe to get an ID faster than regular service. Inefficiency of time in accessing public services in Indonesia is a major problem that relate to bureaucracy. $62.9 \%$ of respondent stated that it is always need many time when regarding bureaucracy in Indonesia; moreover 58\% respondent stated it is easy to bribe the bureaucrats (2015). This study aims to identify factors affecting the review of Bureaucracy in an integrated way, namely recoding 
bureaucrats, implementing the ideal of administrative responsibility and best value for creating good governance.

\section{RESEARCH METHOD}

This research uses descriptive analysis method and qualitative approach. Descriptive analysis is analysing data and information regarding problem in bureaucracy in Indonesia, ethics, and employees behaviour descriptively. Data collection is conducted by literature review. Literture review consists of books related to management, public administration and public policy issues.

\section{RESULT FINDINGS AND DISCUSSION}

Recode meaning to shape values that deliberate people from habit, employer, giving instruction culture, organisation and the way of thinking. Recoding bureaucrats will focus on solving problem culture based on creativity, confident and their ability, without have to wait employer's instruction. Conducting recoding meaning public administration will more ready to face this globalization era. No more rigid bureaucrat culture will exist, because all staffs have confident in giving public service based on their performance. Furthermore, formality of bureaucrat will eliminate because employee do not have to wait employers' instruction but they will based on creativeness to solve problems in a nation, especially in giving public service.

Based on recoding, employers will conduct their duty because they know their ability and the field. Therefore, it will effective in solving problems in our nation. Layers in bureaucracy make instruction also in layers. At traditional public administration where employees conduct their job based on employer's instruction without understand it and no background in the field, hence the results will not effective. However, by conducting recoding, our bureaucrats will more creative in giving public service due to their better creativeness, performance, and understanding to the field. Thus, public service delivery and quality will be improved. For example, in handling flood disaster in Jakarta, (Badan Meteorologi dan Geofisika) BMG employee should not to wait their employee's instruction to help people.

To implement recoding at our bureaucrat needs good regulation in all level government to be a fundamental basic it implementation. Regulation about recoding makes implementation will run smoothly, because the bureaucrats have legal value to regulate their actions. It can be in local level regulation type such as Mayor Regulation at Bandung Citi, West Java, Indonesia in handling problems in their society, inviting meeting and discussion by using social media such as What's Up and or Tweeter.

Recoding functions are to avoid employers dysfunctional instruction, delayed instruction, unnecessary or wasted actions due to wrong information at the field. Recoding also intensely relate to professionalism issue. Employees are professional when they have initiatives, good work performance, capable in handling problems and know what should do or understand their job description. Recoding is also meaning initiatives and value to understanding their duty well, thus any circumstances occurs they will ready to handle them.

The ideal of administrative responsibility values consist of responsiveness, fairness, flexibility, honesty, accountability and competence. Those values are integrated and very important in public administration implementation. Responsiveness is answering and reacting effectively for public's demand. Good responsiveness in solving people problems is urgently needed now days. For example, local government and its staff need to be responsive in handling Porong, Sidoarjo (East Java) mud accident, even though it is not they fault but PT. Lapindo Brantas. However, due to major effect occurs in the field which people had to loose their houses, lands and jobs, then the local and central government need to be responsive in handling the problem.

Responsiveness is the prompt acquiescence by an organization to the popular demands for policy change and responsiveness meaning that the government takes the initiative in the proposal of solutions for problems and even in the definition of problems [3]. Hence, in the Porong case, its local government and the central government need to find the best solution by having policy to resolve the problems. Apparently, after one period of time of the national resolve Porong committee work but the problem has not been resolved. The committee need to be renewed its contract, meaning more fund to spend and ineffective solution up to now. Rp. 7.6 million had been spent for handling the problem, but it has not been resolved effectively yet. People are still suffered and have not got their compensation for their lands and homes. The local and central government have not maximally responsive in handling the problem, especially in pushing PT. Lapindo Brantas to responsible in the case optimally. As starling states "a responsive government must therefore invent processes to determine preferences". For example, local government or central government has to confiscate PT. Lapindo Brantas' assets and use them to pay back to mud disaster's victim [3].

Fairness is very essential in running a nation. Fairness comprise of results as well as procedures in administering a nation [3]. Fairness can create a harmonious society to achieve good governance. To create fair government, there is a need of strong and clean judicial arm of government supported by laws. The bureaucrats need to administer the nation based on law. For example enactment of regulation of No 11 year 2008 about Information and Electronic Transaction Law in Indonesia means improving fairness and Flexibility in gaining services for the people and by the people, especialy in paying taxes through electronic taxation in Indonesia through.

The need of flexibility value becomes the old model of bureaucracy should be eliminated. Bureaucracy should be more flexible in this era in handling problems due to the complexity of the problems and organization's environment. An effort to improve bureaucracy flexibility in Indonesia is by 
using information technology -as one improvement of globalization- wisely. Information and communication technology, such as internet, can improve flexibility in public organization in Indonesia (as famous with inflexibility). For example, by using internet in discussing on line, sharing data and information among units and departments, even inviting people for conducting formal meeting, then coordination will enhance. Meaning there is flexibility. Another example of handling problem by using flexibility in bureaucracy is by using strategic planning and management in handling natural disaster in Jakarta recently. In order to improve the effectiveness of handling the disaster, then bureaucrats should work be more flexible without waiting for superior's instruction to close and open water dam to control the flood at Jakarta.

Honesty is very important in our life, because it can create trust. And trust is very important in our success. If people trust us, then people can cooperate with us to achieve our goal. For example, based on trust creates many foreign investments increase in our nation, and then our nation will improve its welfare. Therefore, honesty is very important as collusion, corruption and nepotism in our nation are considers second biggest in the world. The importance of honesty in our nation that can create trust is stated by Francis Fukuyama. He states that "a nation's wellbeing, as well as its ability to compete, is conditioned by a single, pervasive cultural characteristic: the level of trust inherent in the society". Based on that opinion, a nation's wellbeing is based on trust that creates by its people. Thus, to create trust, the people should have honesty value in our daily life activities. Honesty can be started from small activity in our bureaucrat services to the people. For example, bureaucrat can give service honestly to the people without bribing process through e-sanction at police department. People pay penalty through their bank account.

Current condition of Indonesia public administration at transportation department shows there is a need for improvement. Accidents are occurs at land, sea and air transportation. Public service delivery needs to be improved. Administering safety standard on each vehicles, boat and airplane properly also need to be improved.

A synonym for accountability is answerability [3]. A nation should answer someone's question, meaning the government should face and answer the question or problems that are occur. For example, transportation department or its head need to be more accountable in answering current problems in transportation in Indonesia. Many accidents occur, such as train, ship, and plane accidents, due to personnel fault, terribly infrastructure and mismanagement in transportation department.

Competence means having good work performance, such as demonstrates any initiatives, have good work skill, good work initiative, efficient and effective work activities. Public administration needs competence bureaucrats that work in a nation to achieve its nation's goals. For example, a competence bureaucrat in providing public service to Indonesian will create efficient and effective services demanded by the people. Then, people's satisfaction in having government's services as one of our nation goal can be enhanced. And also important is when obstacles occur, a competence bureaucrat should has initiative to solve them.

Education has an essential role in improving competency. Improving knowledge such as from training also can enhance bureaucrats' knowledge. On the job training will be more effective to improve bureaucrats' knowledge, especially to resolve disaster management's obstacles now days. Earth quake, flood and tsunami disaster management training will affect significantly to improve bureaucrat's competency. So that they do not have to wait their supervisor's instruction about what should be conducted.

Best value is systematically means closer to people, due to services that should be provided are based on people's needs. Best value should be more responsive to the needs of the community. Best value also means providing services that should be accessible to those for whom it is intended. The most important reason why best value is significantly appropriate for local government level is it should be a regular consultation process to discuss services provided and people need. In Indonesia it can be conducted through Musrenbang (discussion among government, society and private sector) effectively.

Therefore, best value principle is very appropriate at local government level. It is because all of service deliveries are based on people needs and local government responsibility. Best value is working based people's needs, thus it is a bottom-up process due to satisfying people orientation. Best value is a framework for ensuring that decentralized units of government focus on efficiency as well as good governance and community consultation; moreover, it is a framework which respects the autonomy of decentralized units while providing a framework that directs them toward efficiency and good government [4]. Best value focuses on local government performance to achieve its good governance. A community consultation method is a two way communication, so that people can articulate their needs and values to the government, especially in creating better policies and good governance as a whole.

Best Value principles are applied in five year time frame at local government level. It is basically a consultation on performance framework. Meaning, people and government have consultation mechanism in order to solve problems and provide better services; and at the end is to create good governance in our nation. Coordination between people and bureaucrats - as the service providers - will improve by conducting this consultation mechanism.

Advantages of implementing best value principles are improving local government accountability, improving whole of bureaucrats response, and encouraging innovation (due to consultation mechanism that can create new and creative ideas from both side - government and people). Moreover, best value principles is not cost or money oriented, because it is based on people's needs - more focus on value for money in the delivery of all services- and not based on compulsory regulation that should be continuously implemented. In 
Indonesia, it can be conducted through PKK (Neighbourhood House) programs' implementation.

It is feasible to implement best value in Indonesia. Best value principles implementation in Indonesia can add to existing monitoring frameworks [4]. Monitoring for services delivery to public in Indonesia is relatively un-integrated way. Each unit, councils, departments, offices has their own monitoring system for their organization. By implementing best value principles, there will be one standard in monitoring bureaucrats performance in delivering public services. There will be one independent commission that effectively measure and control the monitoring system that has been applied in each unit, councils, departments, and offices. Based on above principles that should be implemented in an integrated way and under control of a best value - independent - commission, then there will be better services from bureaucrats.

\section{CONCLUSION}

Public administration is cooperation among people to achieve their goals. In a broader view, public administration is managing bureaucrat's activities to give public services and achieving nation's goals. In this globalization era, where changes rapidly are occurs, there is a need to improve our bureaucracy. The traditional model of bureaucracy need to be changed into more modern bureaucracy in order our nation's goals and objectives can be achieved more effectively, such as more efficient, effective, transparent, accountable public service delivery. In Indonesia case, where coordination, transparency and accountability are still need to be improved, there is a need to enhance our development by implementing: recoding, the ideal of administrative responsibility and best value principles.

Recoding is changing bureaucrat's mind set - in this essay is Indonesian bureaucrats- in order to be more professional and innovative in their working performance. Many chaos, disaster and conflicts occur in our nation need this process in order to solve those obstacles effectively and efficiently. The ideal of administrative responsibility value consists of responsiveness, fairness, flexibility, honesty, accountability and competence. This value is should be inherently present at our bureaucrats in order to achieve good governance in our nation. It should be embedded in our bureaucrats' working process, especially in this era where Indonesia is still facing extremely complex obstacles, including in disaster management. Best value is principles that improve public service delivery by conducting community consultation; people need assessment process, and independent controlling process. This value is very appropriate for local government because its mechanism is focus on local government's effort in providing public services.

Those three factors - recoding, the ideal of administrative responsibility value, and best value - should be conducted in integrated way so that good governance in our nation can be enhanced. Those three factors need to be implanted in bureaucrat's working performance so that it can become organizational culture.

\section{ACKNOWLEDGEMENTS}

According to the problems and solution that the writers argue, there are some acknowledgement can be conducted, namely; community consultation through social media such as what's Up or tweeter, enacting regulation in bureaucratic ethic towards reward and punishment system and public administration innovation should be enhanced, such as electronic administration, electronic government (such as electronic ticketing for public transportation, electronic taxing).

\section{REFERENCES}

[1] Lembaga Administrasi Negara (2001). Menguak Peluang dan Tantangan Administrasi Publik, Bunga Rampai Wacana Admnistrasi Publik, Lembaga Administrasi Negara, Jakarta, 2001.

[2] Hughes, O. (2003), Public Management \& Administration: An Introduction, Palgrave Macmillan, New York.

[3] Starling, G., (2005), Managing the Public Sector, Thomson Wadsworth, Australia.

[4] Macmillan, G., (2007), Best Value, Public Management International Institute, Melbourne. 